\title{
Parvovirus B19-induced Pure Red Cell Aplasia in a Liver Transplant Recipient
}

\author{
Eun Young Lee, M.D., Yonggeun Cho, M.D., Sang-Guk Lee, M.D., and Jaewoo Song, M.D. \\ Department of Laboratory Medicine, Yonsei University College of Medicine, Seoul, Korea
}

\begin{abstract}
Parvovirus B19 infection is known to cause chronic anemia in immunocompromised hosts, including organ transplant recipients. We report the first case of liver transplant recipient with parvovirus B19-induced pure red cell aplasia in Korea. A 57-yr-old female patient with hepatocellular carcinoma due to hepatitis $\mathrm{C}$ virus received a liver transplantation. Two months later, anemia developed and she received periodic red blood cell transfusions. However, chronic anemia persisted and bone marrow examination was performed 8 months after transplantation. Bone marrow aspiration smears showed markedly reduced erythroid precursors with atypical giant pronormoblasts and nuclear remnants with viral inclusions, and characteristic lantern cells were observed in biopsy sections. In addition, parvovirus B19 DNA PCR was positive. She was diagnosed as parvovirus B19-induced pure red cell aplasia and her anemia was improved following intravenous immunoglobulin therapy. (Korean J Lab Med 2010;30:591-4)
\end{abstract}

Key Words : Pure red cell aplasia, Parvovirus B19, Human, Liver transplantation

\section{서 론}

Parvovirus B19는 직경 20-25 nm 크기의 Parvoviridae과 에 속하는 무외피성 단일가닥 DNA 바이러스이다[1]. 주로 호흡 기를 통해 전파되나 혈액이나 혈액산물에 의한 전염도 가능한 것으로 알려져 있다[2]. 소아에서는 전염성 홍반, 성인에서는 무 증상 감염, 급성 관절통 및 관절염 등이 흔하며, 임산부에서 태 내 사산이나 태아수증, 만성 용혈성 빈혈 환자에서는 일과성 재 생불량성 빈혈 등을 유발할 수 있다[3]. 장기이식이나 후천성면 역결핍증후군 등의 면역억제 상태에서는 골수의 적혈모구를 직 접 침범한 parvovirus B19에 대한 중화항체를 충분히 생산하 지 못하여 순수 적혈구 무형성증이 발생한다[3]. 1999년 Lee 등 [4]은 신이식 후 parvovirus B19 감염에 의한 만성 순수 적혈구 무형성증 사례를 보고하였고, 이후에 신이식 환자에서 비슷한

Received: April 29, 2010

Revision received: August 14, 2010

Accepted: October 11, 2010

Corresponding author: Jaewoo Song, M.D.

Department of Laboratory Medicine, Yonsei University College of Medicine, 134 Sinchon-dong, Seodaemun-gu, Seoul 120-752, Korea

Tel : +82-2-2228-6128, Fax : +82-2-313-0956

E-mail : labdx@yuhs.ac

ISSN 1598-6535 (C) The Korean Society for Laboratory Medicine
증례가 여럿 보고되었으나, 아직까지 간이식 후 parvovirus $\mathrm{B} 19$ 에 의한 순수 적혈구 무형성증이 발생한 사례는 국내에서 보고된 적이 없었다. 본 증례는 간이식 후 parvovirus B19 감 염에 의해 발생된 순수 적혈구 무형성증으로, 국내에서는 처음 으로 발생한 증례로 문헌고찰과 함께 보고한다.

\section{증 례}

\section{환자: 57 세/여자}

주소: 빈혈

과거력: 2005년 C형 간염에 의한 간세포성 암으로 진단받고 20 회의 간동맥 화학 색전술(transcatheter arterial chemoembolization)과 고주파절제(radiofrequency ablation)를 받 고, 2008년 7월 간이식을 받았다. 이후 tacrolimus (FK506), prednisolone 및 mycophenolate mofetil 등의 삼중 요법으로 면역억제치료를 하다가 tacrolimus와 deflazacort로 변경하였다.

현병력: 간이식 후 2008년 8월 28일 간생검상 C형 간염이 재발하여 peginterferon, ribavirin 치료를 시작하였다. 빈혈 이 발생한 2008년 10 월 이후 한 달에 4단위의 농축적혈구를 정 기적으로 수혈받았다. 이러한 수혈 치료에도 불구하고 빈혈이 호전되지 않아 원인 규명을 위해 2009년 4월 1일 골수검사를 
실시하였다.

이학적 소견: 내원 당시 활력 징후는 혈압 $141 / 71 \mathrm{mmHg}$, 맥 박수 80회/분, 호흡수 20 회/분, 체온 $37^{\circ} \mathrm{C}$ 이었다. 신체진찰에 서 환자는 만성 병색을 보였으나 의식은 명료하였으며, 결막은 창백하였고, 폐와 심음, 복부 진찰 소견에서 특이 사항은 없었다.

검사 소견: 간이식 8개월 이후 빈혈이 교정되지 않아 원인을 찾기 위해 골수검사를 실시하였으며, 당시 혈액검사에서 백혈 구 $4.35 \times 10^{3} / \mu \mathrm{L}$, 적혈구 $1.96 \times 10^{6} / \mu \mathrm{L}$, 혈색소 $5.7 \mathrm{~g} / \mathrm{dL}$, 평 균적혈구용적(mean corpuscular volume, MCV) $84.7 \mathrm{fL}$, 평 균적혈구혈색소(mean corpuscular hemoglobin, MCH) 29.1 $\mathrm{pg}$, 평균적혈구혈색소농도(mean corpuscular hemoglobin concentration, $\mathrm{MCHC}) 34.3 \mathrm{~g} / \mathrm{dL}$, 혈소판 $208 \times 10^{3} / \mu \mathrm{L}$, 망상 적혈구 $0.04 \%$ 이었다. 화학검사에서는 총빌리루빈 $0.6 \mathrm{mg} / \mathrm{dL}$, $\mathrm{AST} 61 \mathrm{IU} / \mathrm{mL}, \mathrm{ALT} 124 \mathrm{IU} / \mathrm{mL}$, 혈청철 $238 \mu \mathrm{g} / \mathrm{dL}$, 총철결 합능 $248 \mu \mathrm{g} / \mathrm{dL}$, 페리틴 $4,835.1 \mathrm{ng} / \mathrm{mL}$ 이었고 그 외 엽산, 비 타민 B12는 시행하지 않았다. 요화학 검사상 특이소견은 없었 다. 말초 혈액 도말에서 백혈구와 혈소판의 수 및 모양은 정상 이었고 적혈구의 크기 및 모양이 정상인 정구성 정색소성 빈혈 이 관찰되었다. 골수흡입 도말에서 세포충실성은 감소되었으며 과립구와 적혈구비는 15.8:1로 적혈구계가 심하게 감소된 소견 을 보였다. 과립구계 및 거핵구계는 정상 소견을 보였으나 적혈 구계 세포는 전적혈모구(pronormoblast) 같은 초기 적혈구계 세포의 증가 소견을 보였으며 성숙된 적혈구계 세포가 거의 관 찰되지 않았다. 또한 세포가 변성되어 파괴된 봉입체를 함유한 세포들이 관찰되었다(Fig. 1). 골수생검에서 중앙의 투명하게 염색되는 부위(central halo)에 핵내 봉입체를 지닌 lantern 세

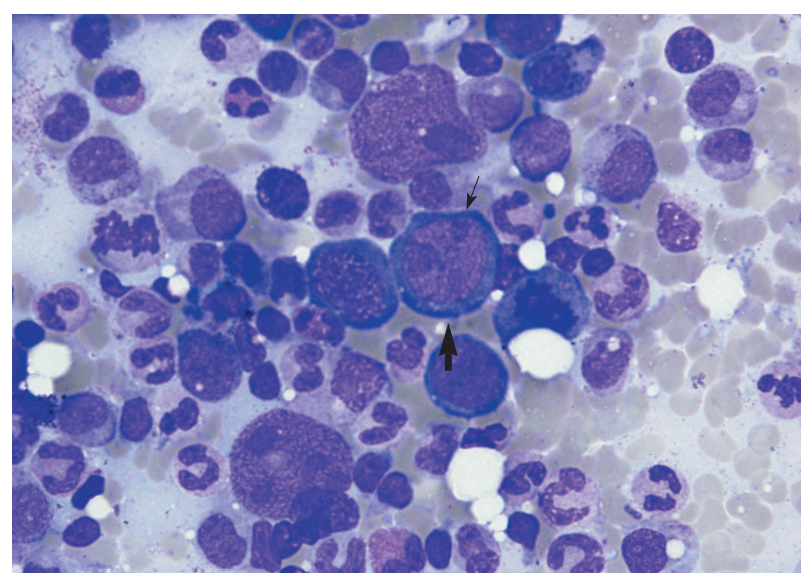

Fig. 1. Bone marrow aspiration smears reveal abnormal giant pronormoblasts with intranuclear inclusion bodies (Wright-Giemsa stain, $\times 1,000)$. The bold arrow denotes an abnormal giant pronormoblast and the single arrow denotes an intranuclear inclusion body.
포가 관찰되었다(Fig. 2). Lantern 세포는 골수흡입 도말에서 관찰된 봉입체를 함유한 거대 전적혈모구의 상대(counterpart) 이다[5]. 이와 같은 골수소견은 parvovirus B19 감염을 시사하 여 parvovirus B19 중합효소연쇄반응검사를 artus RealArt Parvovirus B19 LC PCR reagent (artus biotech, San Francisco, CA, USA)을 이용하여 시행하였고 결과는 양성이었다 (Fig. 3).

치료 및 경과: 골수검사, parvovirus B19 중합효소연쇄반응 검사 결과로 parvovirus B19 감염에 의한 순수 적혈구 무형성

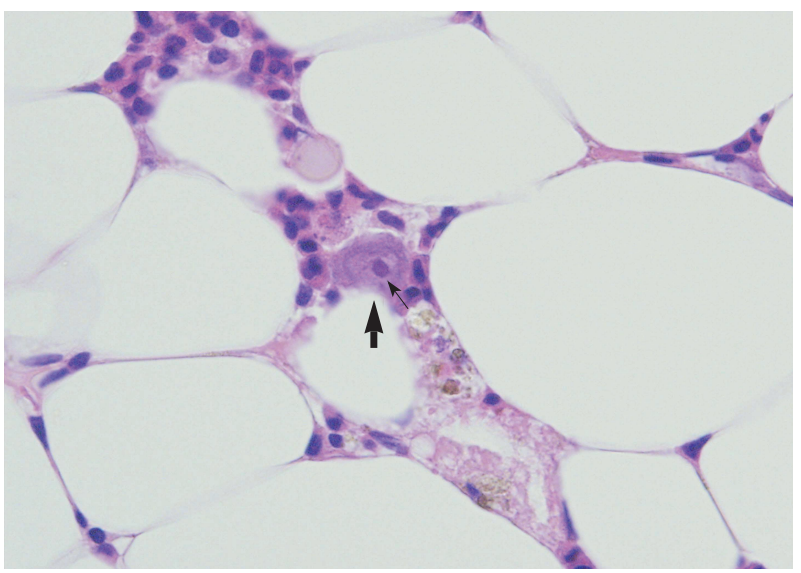

Fig. 2. An abnormal giant erythroblast with glassy, eosinophilic, intranuclear inclusion and a clear central halo (lantern cell) (H\&E stain, $\times 1,000)$. The bold arrow denotes an abnormal giant erythroblast and the single arrow denotes an intranuclear inclusion.

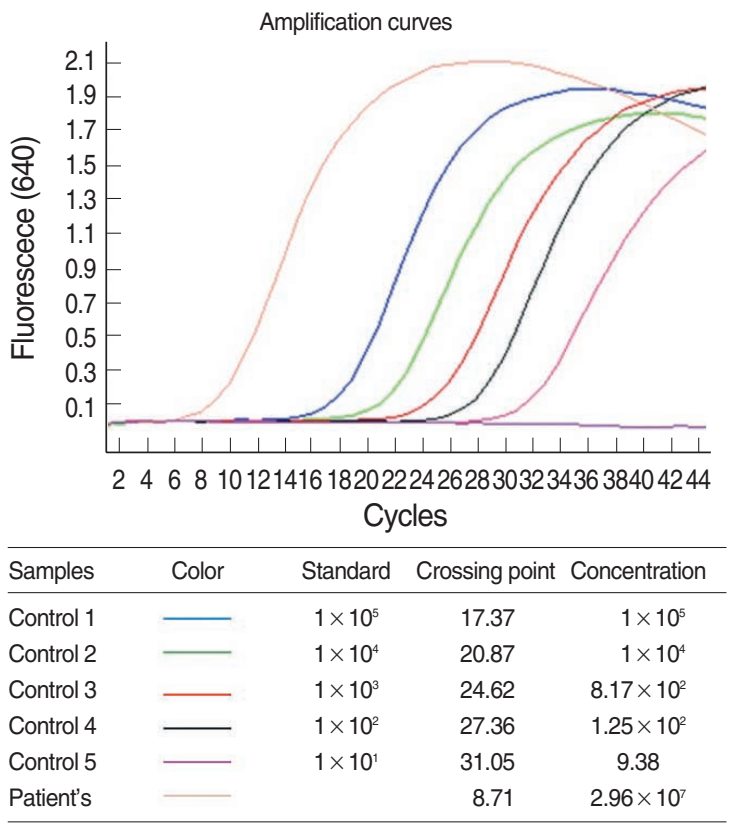

Fig. 3. Parvovirus B19 quantitative PCR. Viral load in the patient was $2.96 \times 10^{7} \mathrm{IU} / \mathrm{mL}$. 
증이 확진되어 면역글로불린 $25 \mathrm{~g}$ 을 생리식염수에 혼합하여 4 일간 정맥으로 투여하였다. 치료 한 달 후 혈액검사에서 백혈구 $4.75 \times 10^{3} / \mu \mathrm{L}$, 적혈구 $3.64 \times 10^{6} / \mu \mathrm{L}$, 혈색소 $11.2 \mathrm{~g} / \mathrm{dL}, \mathrm{MCV}$ $99.7 \mathrm{fL}, \mathrm{MCH} 30.9 \mathrm{pg}, \mathrm{MCHC} 31.0 \mathrm{~g} / \mathrm{dL}$, 혈소판 $159 \times 10^{3} / \mu \mathrm{L}$, 망상적혈구 $2.29 \%$ 로 회복되는 양상을 보였고, 이후 면역글로불 린 $25 \mathrm{~g}$ 을 생리식염수에 혼합하여 4일간 정맥 투여 치료를 반 복하였다. 치료 20 주 후의 혈액검사상 백혈구 $5.42 \times 10^{3} / \mu \mathrm{L}$, 적혈구 $3.98 \times 10^{6} / \mu \mathrm{L}$, 혈색소 $12.8 \mathrm{~g} / \mathrm{dL}, \mathrm{MCV} 97.5 \mathrm{fL}, \mathrm{MCH}$ $32.1 \mathrm{pg}, \mathrm{MCHC} 32.9 \mathrm{~g} / \mathrm{dL}$, 혈소판 $124 \times 10^{3} / \mu \mathrm{L}$, 망상적혈구 $2.84 \%$ 로 회복되었고 이때 시행한 parvovirus B19 중합효소연 쇄반응검사는 음성이었다. 추적 골수검사는 시행하지 않았다.

\section{고 찰}

Parvovirus B19에 감염되면 건강한 사람의 경우 짧은 바이 러스혈증 후 항체가 형성되어 혈액에서 바이러스는 사라진다. 이후 면역글로불린 $\mathrm{G}$ 항체는 재감염에 대한 지속적인 예방역할 을 한다[6, 7]. 하지만 면역기능이 저하된 경우에는 parvovirus $\mathrm{B} 19$ 에 대한 중화 항체를 만들지 못하기 때문에 바이러스혈증이 지속될 수 있으며, parvovirus B19의 적혈구 전구세포(erythroid progenitor cell)에 대한 친화성으로 인하여[4] 적혈구 전구세포가 파괴되면서 만성 순수 적혈구 무형성증이 발생할 수 있다.

Parvovirus B19 감염에 의한 만성 순수 적혈구 무형성증은 여러 면역저하 상태에서 발생할 수 있다. 복합면역결핍질환인 Nezelof 증후군 환자에서 처음으로 보고된 이후[8] 세포파괴 항 암요법을 받은 환자 혹은 후천성면역결핍증 환자, 그리고 면역 억제제를 투여 받은 장기이식 환자에서 발생이 보고되었다. 특 히 간이식 후 parvovirus B19 감염에 의한 순수 적혈구 무형성 증은 국외에서 보고가 있었으나[9-14] 국내에서는 처음으로 발 생한 증례이다.

간이식 환자에서의 빈혈의 원인은 매우 다양하다. 약물에 의 한 골수억제, 위장관출혈, 용혈 등이 있을 수 있으며 parvovirus B19 이외의 거대세포바이러스, Epstein Barr virus, B형 간염 바이러스, C형 간염 바이러스 등의 바이러스 감염과 영양결핍, 응고인자결핍, 정맥류에 의한 위장관출혈 등이 있다. 여러 원인 들 가운데 parvovirus B19 감염의 중요성은 아직 간과되고 있 다. Gallinella 등[14]은 이식 환자 212명의 이식 후 혈청 256개 를 대상으로 후향적으로 parvovirus B19 중합효소연쇄반응검 사를 실시하였다. 58 명의 간이식 환자 75 검체와 59 명의 신이식 환자 70 검체 중 2 명의 간이식 환자에서 양성 결과가 나왔고 신
이식 환자의 검체는 모두 음성이었다. 발병률에 대한 대규모 연 구는 아니지만, 간이식 환자에서 신이식 환자보다 parvovirus $\mathrm{B} 19$ 감염이 드물지 않을 것으로 추정해 볼 수 있다. 간이식 환 자에서 parvovirus B19 감염에 대한 의사들의 인식이 낮아 중 요성이 간과되었던 것으로 생각된다.

간이식 환자에서 빈혈의 원인을 처음으로 규명하는 데 있어 서 다른 원인과의 감별을 위해 망상적혈구를 검사해야 하며, 의 심이 되는 경우 parvovirus B19 DNA의 반복적인 중합효소연 쇄반응검사를 하는 것이 중요하다[15]. 또한 골수검사를 시행하 게 되는데, parvovirus B19에 감염되면 골수흡입 도말에서 뚜 렷한 적혈구계 저형성증과 핵내 봉입체를 함유한 거대 적혈모 구를 발견할 수 있다. 특히 핵내 봉입체를 함유한 거대 적혈모 구는 골수생검에서 더 잘 관찰되는데, 중앙의 투명하게 염색되 는 부위(central halo)에 핵내 봉입체를 지닌 lantern 세포로 보인다[16].

본 환자에서 용혈이나 급성, 만성 출혈의 증거는 없었다. 망 상적혈구의 수적 감소와 적혈구 무형성증은 parvovirus B19 감염에 의한 것 이외에도 mycophenolate mofetil, tacrolimus 등 약물에 의한 것일 가능성도 있다. 하지만 혈청에서 시행한 parvovirus B19 중합효소연쇄반응검사의 양성 결과와 특징적 인 골수소견으로 parvovirus B19 감염을 진단할 수 있었다. 게 다가 면역글로불린 치료로 빈혈이 회복되었고 이후 혈청에서 시행한 parvovirus B19 중합효소연쇄반응검사에서 음성으로 나온 것으로 보아 빈혈의 원인이 약물보다는 parvovirus B19 감염에 의한 것임을 추측할 수 있다.

Parvovirus B19 감염에 의한 만성 순수 적혈구 무형성증은 면역글로불린 정맥 주사로 치료하며 대증요법으로 적혈구 수혈 을 할 수 있다[16]. 이식 환자에서 면역억제제로 많이 사용되는 tacrolimus 투약 중지 후 치료에 대한 반응이 좋았다는 보고가 있고[17] mycophenolate mofetil 중지 후에 빈혈이 호전된 예 [18]도 보고되고 있어 사용하는 면역억제제의 중지 혹은 교체를 고려할 필요가 있을 것으로 생각된다.

면역억제 상태에서는 parvovirus B19에 대한 중화항체를 충 분히 생산하지 못하여 순수 적혈구 무형성증이 발생하는 것으 로 알려져 있는데[3] 신이식에 의한 증례는 국내에서도 여러 차 례 보고된 적이 있다. Parvovirus B19 감염이 간이식 자체에 의한 것보다는 간이식에 동반된 면역저하가 원인이라고 보면 신이식 증례와의 차이가 없는 것이 한계이다. 하지만 parvovirus B19 감염에 의해 발생된 순수 적혈구 무형성증은 각종 면역억 제 상태의 기저질환들마다 각각 해외보고가 있었다. 또한 간이 식 이후 발생은 국내 최초 보고로서, 간이식 환자에서 빈혈의 
원인으로서 parvovirus B19 감염에 대한 의사들의 인식을 높 이고 적절한 치료를 하는 데 있어 도움이 될 것이다.

결론적으로, 간이식 환자에서 원인 미상의 빈혈이 지속되면서 치료에도 호전이 없는 경우 parvovirus B19 감염을 고려해야 한다. 특히 망상적혈구가 감소된 경우, 골수검사와 parvovirus $\mathrm{B} 19$ 중합효소연쇄반응검사를 시행하여 조기에 치료하는 것이 중요하다.

\section{요 약}

Parvovirus B19 감염은 장기이식 환자를 포함하여 면역저하 환자에서 만성 빈혈을 일으킨다. 본 연구에서 저자들은 간이식 환자에서 parvovirus B19 감염에 의한 순수 적혈구 무형성증 을 우리나라에서 최초로 보고하고자 한다. $\mathrm{C}$ 형 간염 바이러스 에 의한 간세포성 암을 진단받은 57세 여자 환자로 간이식을 받 았다. 간이식을 받고 두 달 뒤 빈혈이 발생하여 적혈구 수혈을 주기적으로 받았지만 호전되지 않아 이식한 지 8개월 후에 골수 검사를 시행하였다. 골수흡입 도말에서 적혈구계 저형성증과 거대 전적혈모구들을 관찰할 수 있었고 세포가 변성되어 파괴 된 봉입체를 함유한 세포들이 관찰되었다. 그리고 생검에서 특 징적인 lantern 세포들이 관찰되었다. 또한 parvovirus B19 중합효소연쇄반응검사에서 양성이었다. 환자는 parvovirus B19 감염에 의한 순수 적혈구 무형성증으로 진단받고 면역글로 불린 정맥 투여 치료를 받았다. 이후 환자의 빈혈은 호전되었다.

\section{참고문헌}

1. Cossart YE, Field AM, Cant B, Widdows D. Parvovirus-like particles in human sera. Lancet 1975;1:72-3.

2. Santagostino E, Mannucci PM, Gringeri A, Azzi A, Morfini M. Eliminating parvovirus B19 from blood products. Lancet 1994;343:798.

3. Anderson LJ. Human parvoviruses. J Infect Dis 1990;161:603-8.

4. Lee YJ, So BJ, Chae KM, Jeong BH. A case of pure red cell aplasia due to parvovirus B19 in renal transplantation. Korean J Hematol 1999;34:646-50. (이영진, 소병준, 채권묵, 정병학. 신이식후 Parvovirus B19 감염에 의한 적혈구무형성증 1례. 대한혈액학회지 1999;34:646-50.)

5. Setúbal S, de Oliveira SA, Pires AR, da Fonseca EC, Camacho LA, Seródio AC, et al. Erythrovirus B19 infection in acquired immunodeficiency syndrome: screening by histopathology, immunohistochemistry, and in situ hybridization. Mem Inst Oswaldo Cruz 2006; 101:407-14
6. Kerr JR, Curran MD, Moore JE, Coyle PV, Ferguson WP. Persistent parvovirus B19 infection. Lancet 1995;345:1118.

7. Musiani M, Zerbini M, Gentilomi G, Plazzi M, Gallinella G, Venturoli S. Parvovirus B19 clearance from peripheral blood after acute infection. J Infect Dis 1995;172:1360-3.

8. Kurtzman G, Frickhofen N, Kimball J, Jenkins DW, Nienhuis AW, Young NS. Pure red-cell aplasia of 10 years' duration due to persistent parvovirus B19 infection and its cure with immunoglobulin therapy. N Engl J Med 1989;321:519-23.

9. Ramage JK, Hale A, Gane E, Cohen B, Boyle M, Mufti G, et al. Parvovirus B19-induced red cell aplasia treated with plasmapheresis and immunoglobulin. Lancet 1994;343:667-8.

10. Chang FY, Singh N, Gayowski T, Marino IR. Parvovirus B19 infection in a liver transplant recipient: case report and review in organ transplant recipients. Clin Transplant 1996;10:243-7.

11. Misra S, Moore TB, Ament ME, Busuttil RW, McDiarmid SV. Red cell aplasia in children on tacrolimus after liver transplantation. Transplantation 1998;65:575-7.

12. Liang TB, Li DL, Yu J, Bai XL, Liang L, Xu SG, et al. Pure red cell aplasia due to parvovirus B19 infection after liver transplantation: a case report and review of the literature. World J Gastroenterol 2007;13:2007-10.

13. Nour B, Green M, Michaels M, Reyes J, Tzakis A, Gartner JC, et al. Parvovirus B19 infection in pediatric transplant patients. Transplantation 1993;56:835-8.

14. Gallinella G, Manaresi E, Venturoli S, Grazi GL, Musiani M, Zerbini M. Occurrence and clinical role of active parvovirus B19 infection in transplant recipients. Eur J Clin Microbiol Infect Dis 1999;18:811-3.

15. Ndimbie OK, Frezza E, Jordan JA, Koch W, van Thiel DH. Parvovirus B19 in anemic liver transplant recipients. Clin Diagn Lab Immunol 1996;3:756-60.

16. Florea AV, Ionescu DN, Melhem MF. Parvovirus B19 infection in the immunocompromised host. Arch Pathol Lab Med 2007;131:799804.

17. Wong TY, Chan PK, Leung CB, Szeto CC, Tam JS, Li PK. Parvovirus B19 infection causing red cell aplasia in renal transplantation on tacrolimus. Am J Kidney Dis 1999;34:1132-6.

18. Geetha D, Zachary JB, Baldado HM, Kronz JD, Kraus ES. Pure red cell aplasia caused by Parvovirus B19 infection in solid organ transplant recipients: a case report and review of literature. Clin Transplant 2000;14:586-91. 